地すべり 第 30 巻 第 4 号

Journal of Japan Landslide Society 30-4(1994)

\title{
再滑動型地すべりの移動機構
}

\section{Movement Mechanism of Reslide-type Landslide}

\author{
丸山清 輝* 吉田克 美* \\ Kiyoteru MaruYama Katsumi Yoshida
}

\begin{abstract}
In this report, the writers examined shear characteristic of sliding surface clay and movement mechanism of re-slide type landslides through ring shear test results. Consequently, if sliding force is smaller than residual strength, transformation will not take place and strain will keep null. Because relationship between the ring shear test result $\left(\phi_{r}{ }^{\prime}, W_{L}, W_{P}, I_{p}\right)$ and clay fraction is examined by multivariate analysis, $\phi_{r^{\prime}}$ can be assumed from $W_{L}$ and $W_{P}$.
\end{abstract}

キーワード: 地すべり, 移動機構, 残留強さ

\section{1。まえがき}

わが国では, 毎年のように融雪期, 梅雨期, 台風期に 多くの地すべり災害が発生し, 昭和 61 年度調査によれば 建設省所管の地すべり危険箇所は, 10,288 箇所に達す る1。地すべりの発生は, その発生時期から分かるよう に, 多くの場合は地すべり地塊に融雪水や降雨が浸透し た結果，すべり面における間隙水圧が上昇し，すべり面 のせん断強さが低下することによると考えられている。 そして,このような地すべり斜面の安全率の変化は, す べり面粘土のひずみ制御によるせん断試験から求められ た $c^{\prime}, \phi^{\prime}$ を用いて求められている。ひずみ制御のせん断 試験は, ひずみを等速度で加えた時の土のせん断強さを 測定する試験である。しかし，地すべり斜面では，滑動 力が常に作用しており，この状態で多くの場合，間隙水 圧の上昇によるすべり面のせん断強さの低下が生じ, 地 すべりが発生している。これは，ひずみ制御のせん断試 験とは異なった応力履歴であり, 応力制御のせん断試験 の応力履歴に一致すると考えられる。本来, 安定解析に 用いるせん断強さは, 斜面の応力履歴にできるだけ近い 状態で求めることが望ましい。しかし，応力制御による せん断試験結果を用いた地すべり移動機構に関する研究 は非常に少ない。

そこで，本報告では，再滑動型地すべり（1～5 年に 1 回程度断続的に移動する地すべり）の移動機構について， リングせん断試験機を用いたひずみ制御と応力制御の各 せん断試験を行い検討した。

\section{2. 再滑動型地すべりにおけるすべり面粘土の せん断特性}

降雨及び融雪に起因する再滑動型の地すべりでは，地 すべり地塊に降雨及び融雪水が浸透することにより，す ベり面の間隙水圧上昇 $\rightarrow$ 有効垂直応力の低下 $\rightarrow$ すべり面 のせん断強さの低下 $\rightarrow$ 地すべり発生と言う地すべり移動 機構が考えられる。このような移動機構は単純に考える と，移動層の滑動力とすべり面のせん断強さの応力不均 衡によると考えることができ，地すべりの挙動は応力制 御のせん断試験により説明できると思われる。

応力制御のせん断試験では, せん断応力と変位速度の 間に図－1に示す関係がある2)。すなわち，せん断応力の 増加により土の挙動は, 変位無し $\rightarrow$ 変位 $\rightarrow$ 破壊の各段階 を示す。ここで, 変位無し $\rightarrow$ 変位の境界せん断応力は下

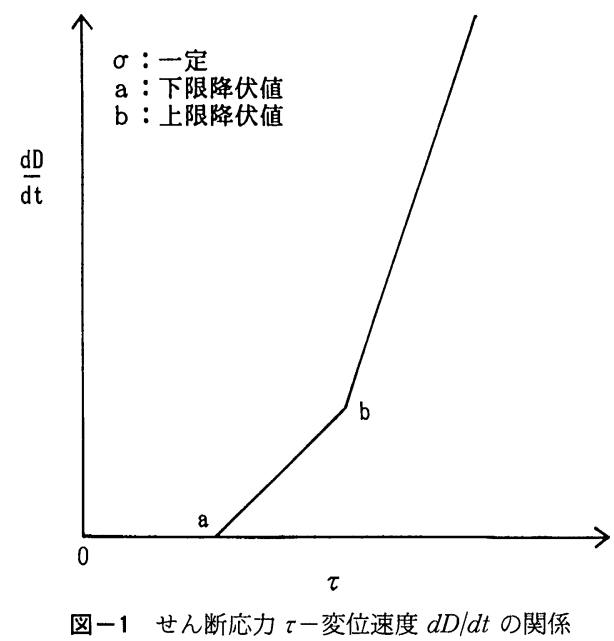


限降伏值, 変位 $\rightarrow$ 破壊の境界せん断応力は上限降伏値に 対応する。また，図ー2に示すように，(1)のせん断応力が 下限降伏值以下では, 変位はせん断応力載荷時のみ発生 し，(2)のせん断応力が下限降伏值と上限降伏值の間では， 変位は生じるが時間の経過とともに収束し破壊には至ら ない。(3)のせん断応力が上限降伏値以上では，急激に変 位を生じ破壊する ${ }^{3)}$ 。一方, 地すべりでは, 移動層の滑動 力とすべり面のせん断強さの応力不均衡により，地すべ りが発生するわけであるから, 有効垂直応力と変位速度 の間に図ー3 の関係が考えられる。ここで, $a$ は上限降伏 值に対応する有効垂直応力であり， $b$ は下限降伏值に対 応する有効垂直応力となり, 有効垂直応力の低下により 土の挙動は, 上・下限降伏值に対応する有効垂直応力を 境に図-10説明と同様になると思われる。

また，再滑動型地すべりは移動と停止を繰り返してい る地すべりであり，すべり面粘土は長い年月をかけて， せん断と圧密及び間吵水圧の上昇による過圧密化という 履歴を繰り返し受けている。したがって, すべり面粘土 のせん断強さが, 全ての応力履歴でせん断試験から求め

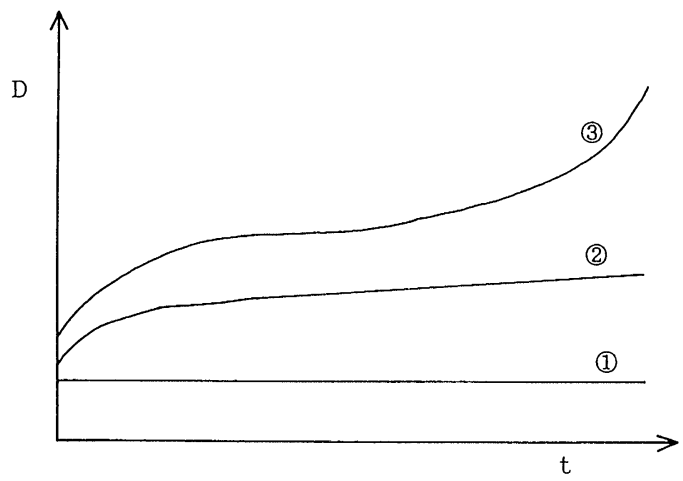

図-2 応力制御せん断試験の時間 $t$-変位 $D$ の関係

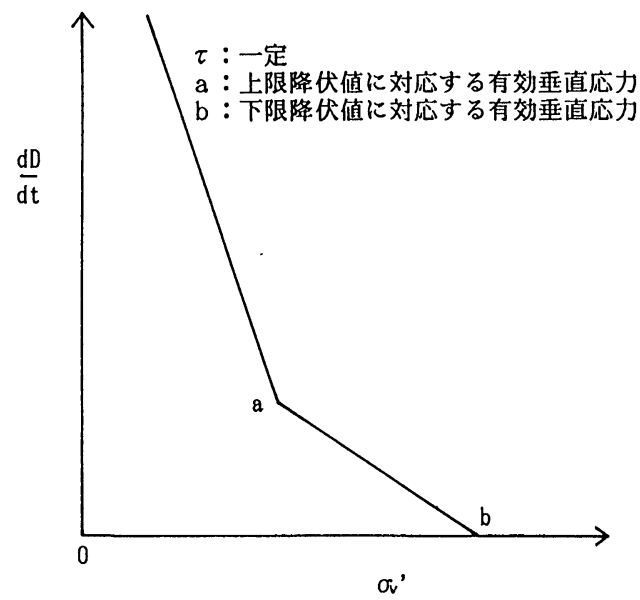

図-3 有効垂直応力 $\sigma_{v}{ }^{\prime}-$ 変位速度 $d D / d t$ の関係
られた有効応力基準による強度定数で求められるか確認 する必要がある。

\section{1 試験方法}

降雨及び融雪に起因する再滑動型の地すべりの移動機 構を，リングせん断試験機で再現する方法としては，以 下のことが考えられる。再滑動型の地すべりにおけるす ベり面のせん断強さは, ピーク強さ, 完全軟化強さ, 残 留強さの各レベルの中で, 過去に繰り返された移動によ り，すべり面の粘土粒子がせん断される方向に沿って配 列されていることから, 完全軟化強さから残留強さのレ ベルにあると考えられる。また，地すべり斜面では，滑 動力が常に作用しており, この状態で多くの場合, 間隙 水圧の上昇によるすべり面のせん断強さの低下が生じ, 地すべりが発生している。このようなことから試験では, せん断強さを残留強さまで低下させた後, 滑動力に相当 するせん断応力を作用させたまま有効垂直応力を減少さ せる操作を行うことにした。

有効垂直応力を減少させるには，(1)間隙水圧を増大さ せる方法と(2)垂直応力を減少させる方法とが考えられる。 (1)の方法は, 供試体の中まで均一に間隙水圧を増大させ る必要がある。また，(2)の方法は，正確に供試体中の間 吵水圧を測定するか, 応力除荷による負の間隙水圧が発 生しないように試験する必要がある。両者では, (2)の方 法が容易であると思われ, 小川等は, この方法により応 力制御のせん断試験を実施している゙)。

試験に用いた試料は，口坂本地すべり(静岡県)，西蒲 生田地すべり (新潟県)，の各すべり面付近の粘土であ る。各地すべりの地質については, 口坂本地すべりは, 中生代〜古第三紀層の砂岩と頁岩層の地すべりであり, 西蒲生田地すべりは，新第三紀層黒色泥岩層の地すべり である。

応力制御のせん断試験は，以下に示す方法で行った。

(1) $420 \mu \mathrm{m}$ フルイを通過させ予備圧密して（圧密試 験と同様に段階的に載荷し，最終的にはせん断試験の 圧密荷重まで載荷する）プレカット試料を作成した後， 試験機にセットし圧密排水条件（せん断速度 0.001 $\mathrm{mm} / \mathrm{min})$ でせん断強さ $\tau$ を残留強さ $\tau_{r}$ まで低下させ る。

（2）残留強さ $\tau_{r}$ に相当するせん断応力 $\tau$ を載荷した まま残留強さに相当する垂直応力の $130 \%, 200 \%$ ぞそ れぞれ圧密する。なお, 圧密打ち切り時間は, せん断 面を十分に圧密するために $3 t_{T}$ 以上とする。

（3）垂直応力 $\sigma_{V}$ を減少させ, 垂直応力と水平変位と の関係を求める。

\section{2 試験結果}

図一4(a)，(b)には, プレカット試料を用いたリングせん 断試験機による圧密排水条件におけるひずみ制御試験結 


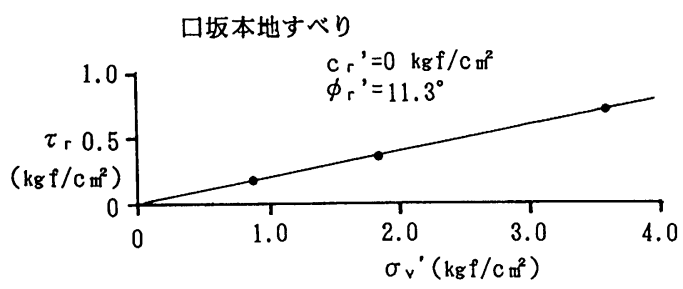

图ー4(a) ひずみ制御リングせん断試験結果

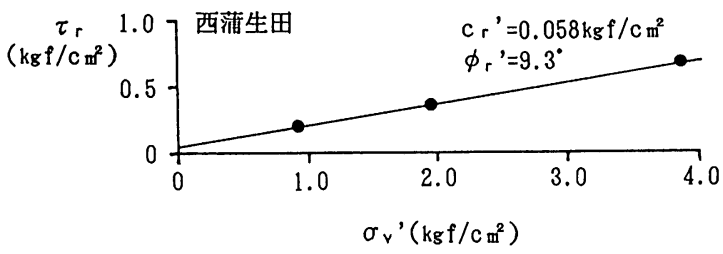

图ー4 (b) ひずみ制御リングせん断試験結果

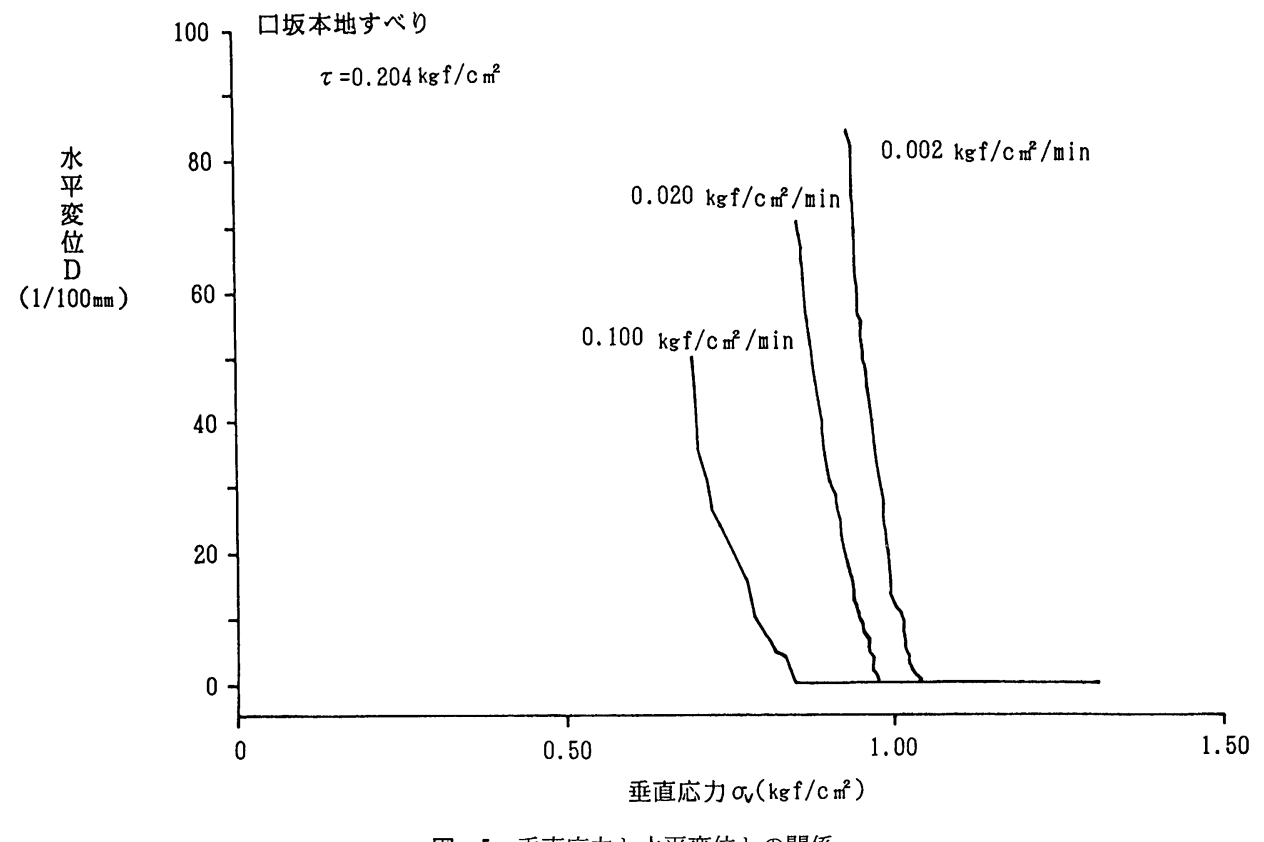

图-5 垂直応力と水平変位との関係

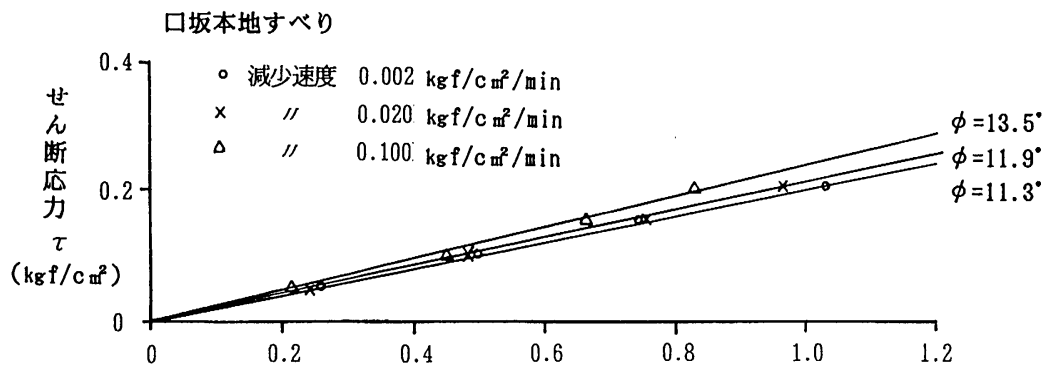

下限降伏值垂直応力 $\sigma_{V}\left(\mathrm{kgf} / \mathrm{c}^{2}\right)$

図－6 下限降伏值垂直応力とせん断応力との関係

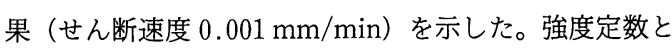
して, 口坂本地すべりについては $\phi_{r}{ }^{\prime}=11.3^{\circ}, c_{r}{ }^{\prime}=0$ $\mathrm{kgf} / \mathrm{cm}^{2}$, 西蒲生田地すべりについては $\phi_{r}{ }^{\prime}=9.3^{\circ}, c_{r}{ }^{\prime}=$ $0.058 \mathrm{kgf} / \mathrm{cm}^{2}$ ，がそれぞれ得られた。

図一 5 は, 試験方法の項で示した応力制御の方法によ り試験を実施した結果を, 口坂本地すべりについて示し たものである。垂直応力の減少により試料の挙動は, 変 位無し $\rightarrow$ 変位 $\rightarrow$ 破壊の各段階を示している。また, 垂直 応力減少速度が早くなると, 変位無し $\rightarrow$ 変位の境界に当 たる垂直応力が小さくなっていることが分かる。この境 界値に当たる垂直応力載荷時のせん断強さが, 下限降伏 值に該当する。

図一6には, 口坂本地すべりの下限降伏値垂直応力と せん断応力との関係を, 垂直応力減少速度毎に示した。 両者の関係は, 直線で示すことができる。また, 垂直応 力減少速度の増大にともない勾配 $\phi$ が急になっている ことが分かる。 
図一7は，口坂本地すべりの垂直応力減少速度と勾配 $\phi$ との関係を示したものである。 $\phi$ は減少速度が 0.01 $\mathrm{kgf} / \mathrm{cm}^{2} / \mathrm{min}$ を境に, 以下では一定值, 以上では大きく なっていることが分かる。このような変化は, 垂直応力 減少速度の増大にともないせん断面に負の間隙水圧が発 生し, 有効垂直応力が試験機に示された垂直応力より大 きくなるためと考えられる。これは試験方法の問題であ り，せん断面の間吵水圧を測定し有効応力で表示すれば, $\phi は$ 減少速度に関係なく一定値になると考えられる。し たがって, 試験では垂直応力の変化にともなう有効垂直 応力を正確に知る必要があり，せん断面の間隙水圧を測 定するか, 負の間隙水圧が発生しないように試験をする 必要がある。図一7において減少速度が $0.01 \mathrm{kgf} / \mathrm{cm}^{2} /$ $\min$ 以下で $\phi$ が一定值を示すのは, せん断面に間隙水圧 が発生せず試験機に示された垂直応力と有効垂直応力が 一致しているためと思われる。このことから, 以下の考 察では, 間隙水圧が発生しないように垂直応力減少速度 を遅くして（垂直応力減少速度 $0.002 \mathrm{kgf} / \mathrm{cm}^{2} / \mathrm{min}$ ) 試 験を行った結果を用いる。

図一8 (a), (b)には, 口坂本地すべり, 西蒲生田地すべり のひずみ制御と応力制御のせん断試験結果をそれぞれ示 した。図中の直線は, ひずみ制御試験により求められた 残留強さの破壊強度線であり, 矢印は今回 の試験における垂直応力の減少経路と下限 降伏值を示したものである。すべり面粘土 の下限降伏值は, ひずみ制御のせん断試験 から得られた残留強さと一致することが分 かる。また，試験方法の(2)では，圧密時間 を約 5 日程度としたが，この圧密によるせ ん断強さの変化は認められない。この他, 今回の試験における初期垂直応力は, 試験 方法の(2)より 130\%とした場合，下限降伏 值に相当する垂直応力に対して OCR は 1.3 となる。また, 初期垂直応力を $200 \%$ と した場合では, OCR は 2.0 となる。各 OCR の下限降伏值は, 図一8 (a), (b)に示したよう にひずみ制御試験から得られた残留強さの 破壊強度線上に位置しており, OCR の増大 による $\phi^{\prime}$ の増大は認められない。

矢田部等は, 再滑動型地すべりのすべり 面粘土のせん断特性を三軸圧縮試験により 求めた結果, 有効応力基準による強度定数 は, せん断と圧密及び間隙水圧の上昇によ る過圧密化の影響を受けないと報告してい る5)。また, 小川等は, 有効垂直応力の低下 によるすべり面粘土の過圧密化にともなう 強度特性について試験を行い, すべり面粘
土は過圧密比 (OCR) の増大にともない $\phi^{\prime}$ も増大すると 報告している ${ }^{4)}$ 。今回の結果は, 矢田部等の結果と一致 し，小川等の結果とは異なるものである。

小川等の結果と異なった原因は, 垂直応力を減少させ た場合, 矢田部等が述べているように王, 十分に供試体を 膨張させずに試験を行うと負の間隙水圧が発生し, 試験 機に示された垂直応力より大きな有効垂直応力が作用す るため, 大きなせん断強さを示すことが考えられる。

以上のことから，すべり面粘土の応力制御のせん断試 験から求められた下限降伏值は, 過圧密比に関係なくひ

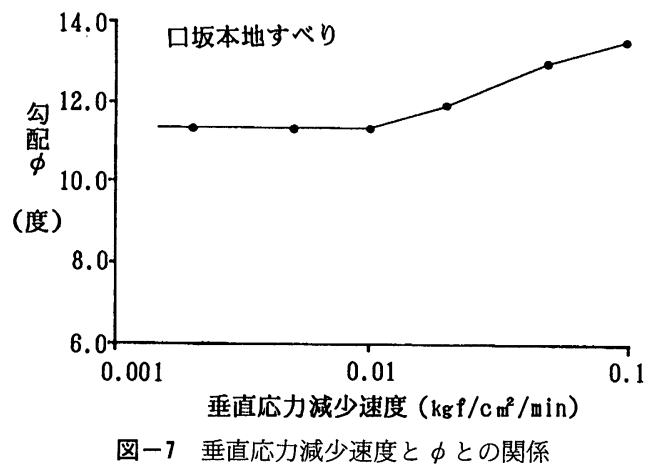

図ー8 (a) ひずみ制御と応力制御のせん断試験結果

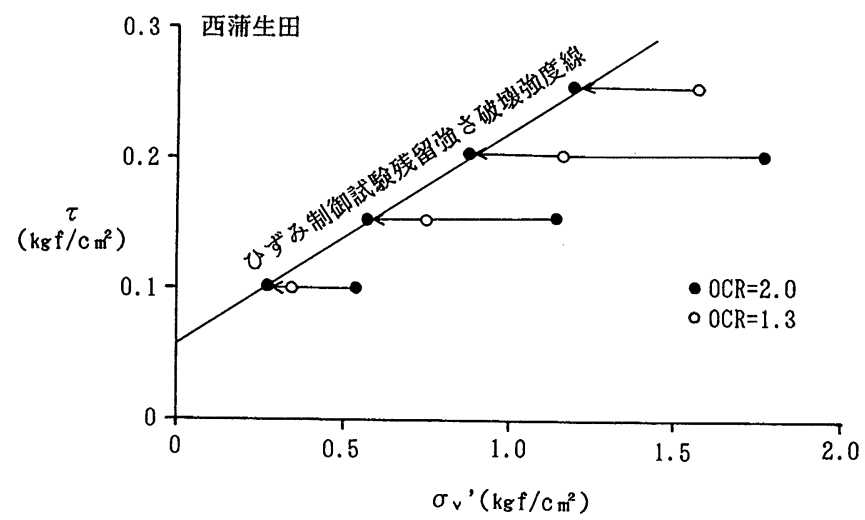

図ー8 (b) ひずみ制御と応力制御のせん断試験結果 
ずみ制御のせん断試験から得られた残留強さと一致する ことが分かった。また，すべり面粘土は，せん断応力が 残留強さより小さい場合, 変位を生じることなく残留強 さまでせん断応力に抵抗できることが分かった。この他， すべり面粘土の残留強さは，せん断と圧密及び間隙水圧 の上昇による過圧密化の影響を受けず，せん断試験から 求められた有効応力基準による強度定数で求められるこ とが再確認された。

\section{3. 残留せん断強さの推定}

すべり面粘土の下限降伏值は，ひずみ制御のせん断試 験から得られた残留強さと一致することから, 残留強さ は, 再滑動型地すべりが移動するか否かを示す重要な土 質強度定数となる。そこで, 残留強さを示す際の内部摩 擦角 $\phi_{r}{ }^{\prime}$ の推定法について検討した。

Voight $^{7)}$ や Hopkins ${ }^{8)}$ 等は, $\phi_{r}{ }^{\prime}$ が塑性指数 $I_{p}$ 及び粘 土分 $(<2 \mu \mathrm{m})$ 含有量と相関があることを示した。そし て，これらの相関関係から $\phi_{r}{ }^{\prime}$ を求める式が提案されて いる。そこで, 筆者らが実施した試験結果について, 同 様な方法で整理を行ってみた。

衰ー1 リングせん断試験結果

\begin{tabular}{|c|c|c|c|c|c|c|c|}
\hline No. & 地すべり & 採取位置 & $\begin{array}{l}\text { 残留強さ } \\
\phi_{r^{\prime}} \text { (度) }\end{array}$ & $\begin{array}{c}W_{L} \\
(\%)\end{array}$ & $\begin{array}{l}W_{P} \\
(\%) \\
\end{array}$ & $\overline{I_{P}}$ & 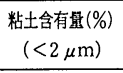 \\
\hline 1 & 木古庭（神奈川） & 移助㬝 & 19.9 & 80 & 27 & 53 & 50 \\
\hline 2 & $" 1$ & " (風化岩) & 23.8 & 36 & 16 & 20 & 34 \\
\hline 3 & 猿供養寺（新潟） & 基岩 & 19.9 & 69 & 22 & 47 & 39 \\
\hline 4 & 他の瀬（大阪） & $"$ & 26.0 & 61 & 24 & 37 & 3 \\
\hline 5 & $n$ & 深度 $2.7 \mathrm{~m}$ & 30.0 & 66 & 30 & 36 & 30 \\
\hline 6 & 野比（神奈川） & 潹度 $2.7 \mathrm{~m}$ & 30.2 & 66 & 30 & 36 & - \\
\hline 7 & $\prime \prime$ & 深度 $5.3 \mathrm{~m}$ & 34.2 & 67 & 30 & 37 & 30 \\
\hline 8 & $" 1$ & 深度 $11.3 \mathrm{~m}$ & 30.5 & 52 & 28 & 24 & 2 \\
\hline 9 & 清水山（曼野） & すべり面粘土 & 3.6 & 216 & 24 & 192 & 49 \\
\hline 10 & 下地藏寺（高知） & 移動層 & 26.7 & 42 & 20 & 22 & 27 \\
\hline 11 & 赤崎（新潟） & すべり面粘土 & 4.8 & 200 & 21 & 180 & 52 \\
\hline 12 & $"$ & " & 7.8 & 274 & 45 & 229 & 33 \\
\hline 13 & 口坂本 (静岡) & すべり面粘土 & 11.3 & 78 & 11 & 67 & 33 \\
\hline 14 & 西蒲生田（新潟） & $"$ & 9.3 & 86 & 12 & 74 & 42 \\
\hline
\end{tabular}

表-1には, 試験結果を示した ${ }^{9)} 。 \phi_{r}{ }^{\prime}$ は, 試験機にリン グせん断試験機を用い, 地すべり現場で採取した試料か ら主にスラリー試料を作成して求めた值である。

図 -9 は, 粘土含有量 $(<2 \mu \mathrm{m})$ と $\phi_{r}{ }^{\prime}$ との関係を示 したものである。これは, $\phi_{r}{ }^{\prime}$ が土粒子の粒径に関係する と考えられることを根拠に整理されたものである。粘土 含有量は 2～52\%の範囲で, また, $\phi_{r}{ }^{\prime}$ は 3.6〜34.2 度の 範囲で各々分布している。両者の関係には幅があり, 明 瞭な関係は認められない。

図-10には, $I_{p}$ と $\phi_{r}{ }^{\prime}$ との関係を示した。これは, $\phi_{r}{ }^{\prime}$ が粘土粒子の物理化学及び鉱物特性に影響されると考え られることから, その特性を直接的に反映していると思 われる $I_{p}$ との関係で整理したものである。 $\phi_{r}{ }^{\prime}$ が 20 度 以上では $I_{p}$ は 50 以下であり, $\phi_{r}{ }^{\prime}$ が 10 度以下では $I_{p}$ は 60 以上に急激な増大を示している。両者の関係には幅が あり, 粘土含有量 $(<2 \mu \mathrm{m})$ と $\phi_{r}{ }^{\prime}$ との関係と同様に明 瞭な関係は認められない。

このような検討は, 日本においても矢田部等 ${ }^{10)}$ や宜 保 ${ }^{11)}$, 小川等 ${ }^{12)} に よ り$ 行われている。しかし, どの場合 も明瞭な関係は認められていない。そこで, 多変量解析 を行い再度検討した。すなわち, 目的変数として $\phi_{r}{ }^{\prime}$ を, 説明変数として液性限界 $W_{L}$, 塑性限界 $W_{P}$, 塑性指数 $I_{p}$, 粘土含有量をそれぞれ用いて重 回帰分析を行うものである。用いたデー夕は, 表一 1 に示す通りである。

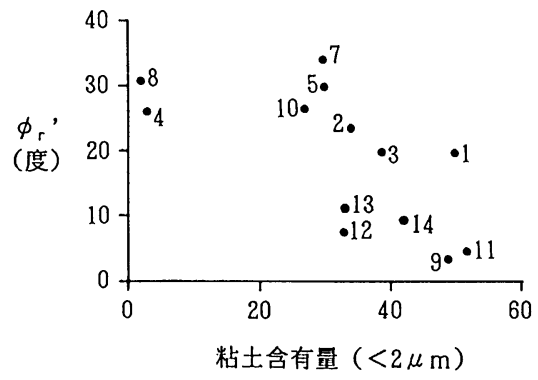

図ー9 粘土含有量 $(<2 \mu \mathrm{m})$ と $\phi_{r}{ }^{\prime}$ との関係

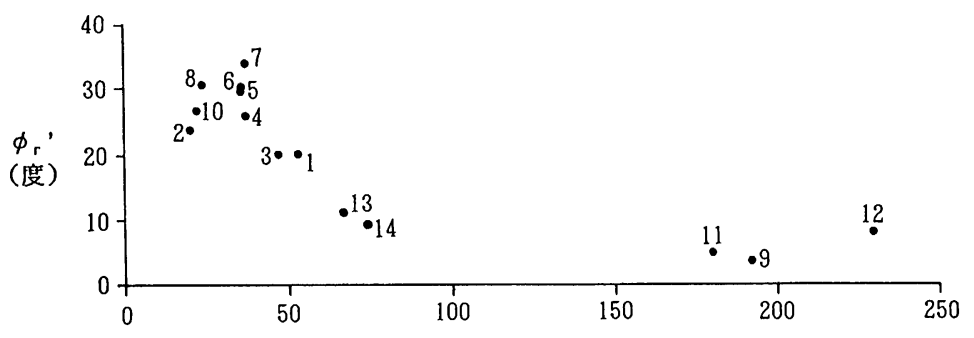

塑性指数 $I_{P}$

図-10 $I_{p}$ と $\phi_{r}{ }^{\prime}$ との関係 
重回帰分析では, 説明変数の選択を行っている。これ は, 目的変数の推定に役立つ主要な説明変数を求めるた めである。その結果, $W_{L}$ と $W_{P}$ が選ばれ, $I_{p}$ と粘土含有 量は選ばれなかった。以下に求められた式を示す。

$$
\begin{aligned}
y=15.29420-0.15313 x_{1}+0.81527 x_{2} \\
\text { ここで, } y: \phi_{r}{ }^{\prime} \\
x_{1}: W_{L} \\
x_{2}: W_{P} \text { である。 }
\end{aligned}
$$

また, 分散分析の結果では, $F_{0}=87.6595>F_{11}^{2}(0.05)=$ 3.982 となり，回帰が有意であることが示された。この 他， $W_{L}, W_{P}$ の回帰係数の検定では,

$$
W_{L}: F_{0}=168.254>F_{11}^{1}(0.05)=4.844
$$$$
W_{P}: F_{0}=66.4784>F_{11}^{1}(0.05)=4.844
$$

となり，どの回帰係数もゼロではないと言えることから， $\phi_{r}{ }^{\prime}$ の推定に $W_{L}$ と $W_{P}$ が使用できることが示された。

従来から $\phi_{r}{ }^{\prime}$ の推定に用いられていた $I_{p}$ と粘土含有 量が選ばれなかったことについては, 以下のことが考え られる。 $I_{p}$ は, $W_{L}$ と $W_{P}$ の差で表される值である。した がって, 同じ $I_{p}$ でも $W_{L}$ と $W_{P}$ は大きなものから小さな ものまで存在するので相対的な指標と考えられ， $I_{p}$ が粘 土粒子の物理化学及び鉱物特性を一義的に表せないこと を意味していると解釈できる。このために， $I_{p}$ が説明変 数として選ばれなかったと考えられる。また，粘土含有 量については，その量が増すと $\phi_{r}{ }^{\prime}$ が低下すると考えら れている。しかし, すべり面粘土は, 石英, 長石, 輝石 等の鉱物やクロライト, カオリナイト，イライト，マイ カ,スメクタイト等の粘土鉱物から構成されている。表一 2 は, 矢田部等が行った各種粘土鉱物の粘土含有量と残 留強さとの関係を示したものである ${ }^{10)}$ 。粘土含有量は, 多 い方からクロライト, イライト, マイカ, カオリナイト の順になっている。しかし， $\phi_{r}{ }^{\prime}$ は，小さい方からマイ カ, イライト, クロライト, カオリナイトの順になって おり，必ずしも $\phi_{r}{ }^{\prime}$ の大小は粘土含有量の多少と関係し ないことを示している。特に，カオリナイトとクロライ トでは, カオリナイトの粘土含有量がクロライトの 4.7 倍もあることから， $\phi_{r}{ }^{\prime}$ はクロライトの方が大きくなる はずであるのに対して, 逆にカオリナイトの方が 1.5 倍

\begin{tabular}{|c|c|c|}
\hline 粘土鉱物 & $\begin{array}{c}\text { 粘土含有量 } \\
(<2 \mu \mathrm{m}) \quad(\%)\end{array}$ & $\begin{array}{c}\phi_{r}^{\prime} \\
\text { (度) }\end{array}$ \\
\hline マ 1 力 & 13.0 & 11.8 \\
\hline イライト & 12.3 & 15.9 \\
\hline クロライト & 7.5 & 17.5 \\
\hline カオリナイト & 35.0 & 25.6 \\
\hline
\end{tabular}
大きくなっている。これらのことから，すべり面粘土の $\phi_{r}{ }^{\prime}$ は, 粘土粒子の物理化学及び鉱物特性や粘土含有量 等が複雑に絡み合って出てきた值であり, 単純に粘土含

表－2 粘土含有量と $\phi_{r^{\prime}}$ (矢田部他 1991 年による)

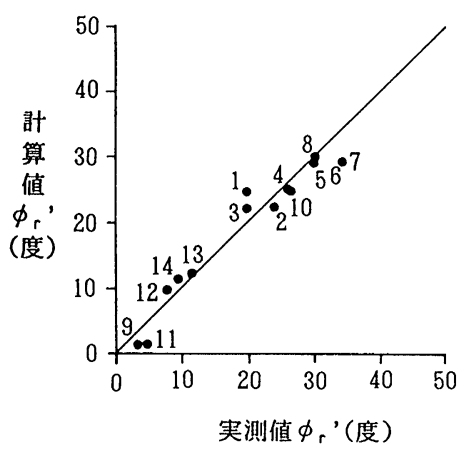

図-11 実測値と計算値との関係

有量だけでは定まらないと考えられる。このため，粘土 含有量が説明変数として選ばれなかったものと思われる。 図-11には, 実測値と(1)式を用いて $W_{L}$ と $W_{P}$ から $\phi_{r}{ }^{\prime}$ を求めた計算值との関係を示した。両者はほぼ一致 しており, 重相関係数は 0.97 であった。なお, 液性限界・ 塑性限界試験は, JIS の試験法 ${ }^{13)}$ にもとづいて実施する のであるが，すべり面粘土は粘土分が多いため，試験法 の一部を以下に示すものに変えている。すなわち, 試料 は, JIS では空気乾燥させたものを用いるのに対して, 本 試験では現場で採取した含水状態のまま $420 \mu \mathrm{m}$ フルイ を通過させたものを用いている。また, 液性限界試験で は, 含水比の低い試料から順に試験し, 試料をなじませ るためには半日以上寝かせ, 練り返し時間も 15 分以上 取っている。

以上，今回実施したリングせん断試験結果を用いて $\phi_{r}{ }^{\prime}$ と $W_{L}, W_{P}, I_{p}$, 粘土含有量との関係を多変量解析に より検討した。その結果, データが少ないので断定する ことはできないが, 筆者らの試験結果では, $W_{L}$ と $W_{P}$ か ら $\phi_{r}{ }^{\prime}$ が推定できることが分かった。しかし， $c_{r}{ }^{\prime}=0$ で ない場合もあることから, 正確な残留強さはリングせん 断試験を実施し求める必要がある。

\section{4 . 再滑動型地すべりの移動機構}

図-12 は, 今回の試験結果をもとに, 再滑動型地すべ りの移動機構を示したものである。ここで, 現状の地す ベり斜面の安全率が(2)式により $F_{S}=1.0$ で, 滑動力によ る移動層の圧密が十分進み, 地すべり 斜面のどの部分で も移動が認められない状態にあるとする。

$$
\begin{aligned}
& F_{S}=\frac{\sum c_{r}^{\prime} \Delta l_{i}+\sum\left\{\left(W_{l} \cos \alpha_{1}-\Delta l_{i}\left(u_{i}-\Delta u_{i}\right)\right\} \tan \phi_{r 1}^{\prime}\right.}{\sum W_{i} \sin \alpha_{i}-\sum P_{R}} \\
& C_{r}{ }^{\prime}, \phi_{r^{\prime} i} \text { : すべり面の残留強度定数 } \\
& \Delta l_{i} \text { : すべり面長 } \\
& W_{i} \text { : スライス重量 } \\
& \alpha_{i}: \text { すべり面と水平面との成す角度 } \\
& u_{i}: \text { 間㭞水圧 }
\end{aligned}
$$


$\Delta u_{i}:$ 防止工事で低下させる間隚水圧

$P_{R}:$ 防止工事で低下させる滑動力

移動は，単純に考えるとすべり面のせん断強さである 上限降伏值 $\tau_{u}$ と下限降伏值 $\tau_{L}$ (ひずみ制御試験残留強 さ）に対して滑動力を比較することにより，a，b，cの各 領域に分けられる。a 領域では, 滑動力が上限降伏值より 大きいことから移動は連続的に生じる。b 領域では, 滑動 力が下限降伏值より大きく上限降伏值より小さいことか ら移動は断続的に生じる。c 領域では, 滑動力が下限降伏 值より小さいことから移動は生じない。図一12 は, 地す

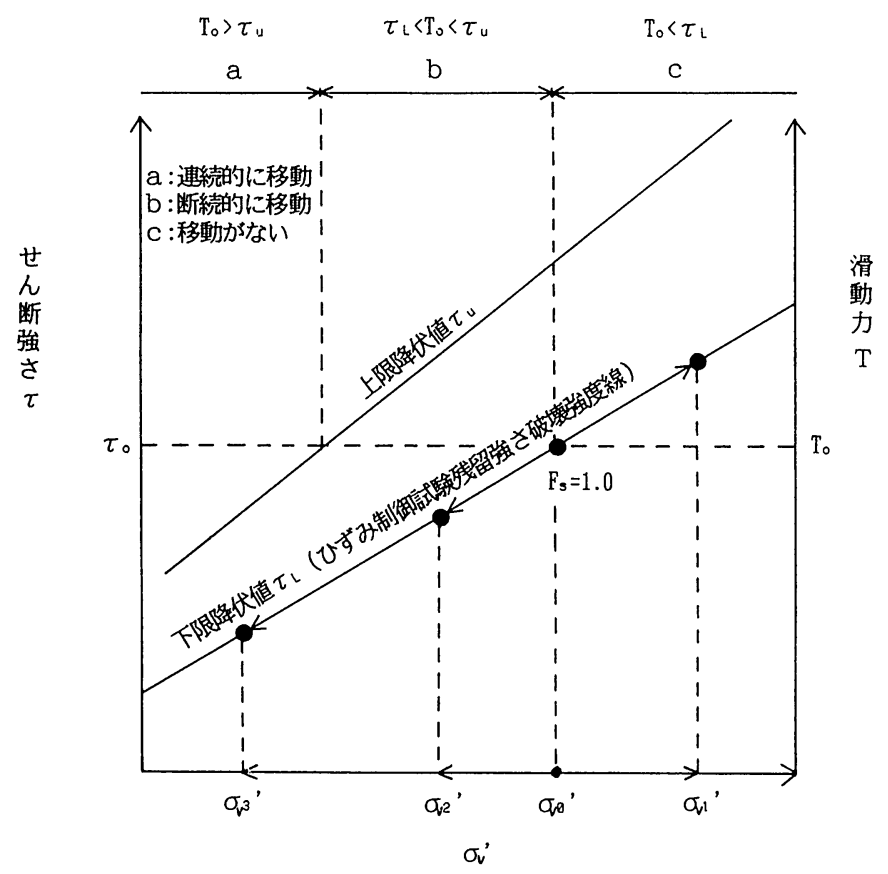

図ー12 再滑動型地すべりの移動機構

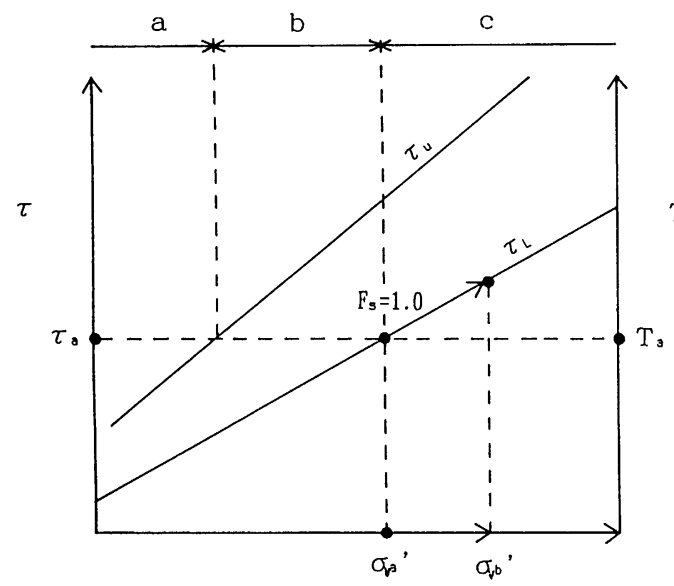

$\sigma^{\prime}$

図ー13(a) 地下水排除工による応力の変化
ベりが間隙水圧の上昇によって生じた場合の移動機構で ある。間吵水圧が上昇し， $\sigma_{V 0}^{\prime} \rightarrow \sigma_{V 2}^{\prime} に な り b$ 領域に入っ

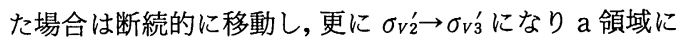
入った場合は連続的に移動する。逆に間隙水圧が低下し， $\sigma_{V 0}^{\prime} \rightarrow \sigma_{V 1}^{\prime}$ になり c 領域に入った場合, 移動は生じない。

また, 防止工事では, 現状の安全率が $F_{S}=1.0$ の場合 に, 将来の豪雨時等でも地すべり斜面全体で移動を生じ ないように，(2)式を用いて現状安全率を計画安全率まで 高める。ここで, 防止工事に地下水排除工を用いた場合 は, 図ー13(a)に示すように(2)式の $\Delta_{u}$ により間隙水圧を 低下させ, 有効応力を $\sigma_{V}^{\prime} a \sigma_{V}^{\prime} b$, すべり 面のせん断強さを $\tau_{a} \rightarrow \tau_{b}$ にそれぞれ増 大させる。また，抑止工等を用いた場合 は, 図一13(b)に示すように(2)式の $P_{R} に$ より滑動力を $T_{a} \rightarrow T_{b}$ に減少させ $\mathrm{c}$ 領 域の中に入れる。

なお, 計画安全率の設定では, 安定計 算に下限降伏值（残留強さ）を用い, 安 全率を最悪の応力状態でも地すべり斜面 全体で移動が生じないことを前提として いることから, 一般全応力法 ${ }^{14)}$ のように せん断時に発生する間隙水圧を考慮する 必要はない。

\section{5. まとめ}

本報告では，再滑動型地すべりの移動 機構についてリングせん断試験を行い検 討した。その結果は, 以下に示す通りで ある。

（1）再滑動型地すべりにおけるすべり 面粘土のせん断特性を調べるために, 応力制御のリングせん断試験を行っ

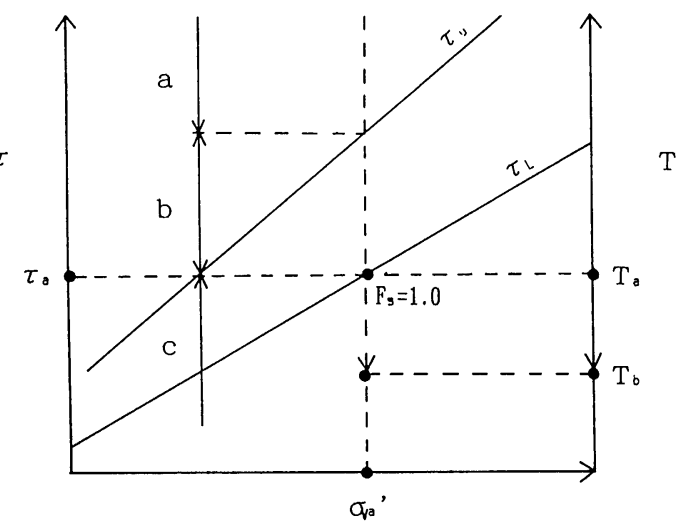

$\sigma_{v}^{\prime}$

図-13 (b) 抑止工等による応力の変化 
た結果，すべり面粘土の下限降伏值は，過圧密比に 関係なくひずみ制御のせん断試験から得られた残留 強さと一致することが分かった。また，すべり面粘 土は, せん断応力が残留強さより小さい場合, 変位 を生じることなく残留強さまで抵抗できることが分 かった。この他, すべり面粘土の残留強さは, せん 断と圧密及び間隙水圧の上昇による過圧密化の影響 を受けず，せん断試験から求められた有効応力基準 による強度定数で求められることが再確認された。

(2) 筆者らが実施したリングせん断試験結果を用いて $\phi_{r}{ }^{\prime}$ と $W_{L}, W_{P}, I_{p}$, 粘土含有量との関係を多変量 解析により検討した結果, デー夕が少ないので断定 することはできないが, $W_{L}$ と $W_{P}$ から $\phi_{r}{ }^{\prime}$ が推定 できることが分かった。しかし，正確な残留強さは， $c_{r}{ }^{\prime}=0$ でない場合もあることからリングせん断試 験を実施し求める必要がある。

（3）今回の試験結果をもとに再滑動型地すべりの発生 機構について検討した結果, 移動は, 上限降伏值 $\tau_{u}$ と下限降伏值 $\tau_{L}$ （ひずみ制御試験残留強さ）に対し て滑動力を比較することにより, a 領域(連続的に移 動する), b 領域 (断続的に移動する), c 領域 (移動 しない) に分けられる。

（4）防止工事を計画する際の安定解析では, すべり面 粘土の下限降伏值がひずみ制御のせん断試験から得 られた残留強さと一致することから，この残留強さ を用いることができる。また，計画安全率の設定で は, 最悪の応力状態でも地すべり斜面全体で移動が 生じないことを前提としているため, 安定解析に一 般全応力法のようなせん断時に発生する間隙水圧を 考慮する必要はない。

最後に, 本報告をまとめるにあたり, 建設省土木研究
所地すべり研究窒吉松弘行室長には，有益な助言を頂い た。ここに感謝の意を表します。

\section{参考文献}

1）建設月報，pp. 62 63，1987，6月

2 ) 村山朔郎, 柴田 徹: 粘土のレオロジー的特性について, 土木学会論文集, No. 40, pp. 1〜31，1956

3 ) 柴田 徹: 基礎工学ハンドブック, pp. $62 \sim 65$, 朝倉書 店, 1969

4) 小川正二, 池田俊雄, 和田 正, 目黒和則: 有効垂直応力 の減少を考慮した地すべり斜面の安定解析,第 20 回土質 工学研究発表会概要集, pp. 1439 1440, 昭和 60 年 6 月

5 ) 矢田部龍一, 八木則男, 榎 明潔: 乱さない地すべり粘土 のせん断特性, 地すべり, Vol. 26, No. 4, pp. 3〜9, 1990 年

6 ) 矢田部龍一, 八木則男, 榎 明潔: 有効応力よりみた地す ベりのすべり層の粘性土の強度定数, 地すべり, Vol. 28, No. 2, pp. 20 26, 1991

7 ) Voight, B.: Correlation between Atterberg Plasticity Limits and Residual Shear Strength of Natural Soils, Geotechnique, Vol. 23, pp. 265 267, 1972

8 ) Hopkins, T.C., Allen, D.L., Deen, R.C.: Effects of Water on Slope Stability; Kentucky Bureau of Highways, Research Report KYHPR 68〜48, pp. $1 \sim 41,1975$

9 ）中村浩之, 石黒 互, 吉田克美: 地すべり粘土の力学強度 特性, 土研資料第 2570 号, 昭和 63 年 3 月

10）矢田部龍一,八木則男, 榎 明趽: 破砕帯地すべり地の粘 性土のリングせん断特性: 土木学会論文集, No. 436, pp. 93〜 101，1991 年 9 月

11）宜保清一: すべり面付近泥岩の残留強さ一残留せん断抵 抗角 $\phi_{r}$ と塑性指数 $I_{p}$ との関係一, 第 24 回土質工学研 究発表講演集, pp. 595〜 596, 1989 年

12）小川正二: 地すべり地を考えた土質力学（その 2)一大変 位を受ける土のせん断強さ一,地すべり技術, Vol. 7, No. 1, pp. $21 \sim 25,1990$ 年

13）土質試験法，土質工学会

14）望月秋利, 三笠正人: フィルダム安定解析法一一般全応 力法と有効応力法の比較 - , 土と基礎, 32-4, pp. 19 26, 1984

（原稿受理日 平成 5 年 1 月 13 日） 
有限要素法による地すへり斜面の漫透流解析と光れに基づいた斜面安定解析

「地すべり」Vol. 30, No. 4 (通巻第 116 号) pp. 1～11，1994 年（平成 6 年） 3 月

稲葉 一茂, 吉田 昭治, 竹内 伸一, 中野 俊郎, 佐藤 修

有限要素法による新簡易解析法によって, 浸水性の異なる土層区分とすべり面を難透水層と仮定した 2 次元水 理モデルを，地下水圧の 2 次元的な観測データと同程度の精度でもって同定した。このモデルによって，すべり 面に沿った 2 次元的な間吵水圧分布を求めて安定解析を行った結果, 例えば，東虫亀地すべり地では，すべり面

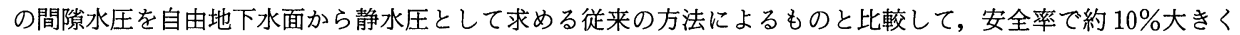
なった。

\section{再滑動型地すべりの移動機構}

「地すべり」Vol. 30, No. 4（通巻第 116 号）pp. 12１9, 1994 年（平成 6 年）3月 丸山 清輝, 吉田 克美

本報告では，再滑動型地すべりの移動機構についてリングせん断試験を行い，すべり面粘土のせん断特性，再 滑動型地すべりの移動機構を検討した。その結果, 滑動力が残留強さより小さい場合, 変位を生じることなく残 留強さまで滑動力に抵抗できることが分かった。また, リングせん断試験結果を用いて $\phi_{r}{ }^{\prime}$ と $W_{L}, W_{P}, I_{p}$, 粘 土含有量との関係を多変量解析により検討した結果， $W_{L}$ と $W_{P}$ から $\phi_{r}{ }^{\prime}$ が推定できることが分かった。

マスムーブメントの性質と物質構成・水・応力場

「地すべり」Vol. 30, No. 4 (通巻第 116 号) pp. 20 27, 1994 年（平成 6 年） 3 月 中山 康

マスムーブメントは, 物質構成とどのような応力場に置かれているかで性質が規定される。とくに土の場合に は粒度組成が大きな意味を持ってくる。近年発表された数多くの研究成果を基にして，これを検討した。

\section{DTM 及び衛星データを用いた地すべり危険地域の抽出}

「地すべり」Vol. 30, No. 4（通巻第 116 号）pp. 28～35, 1994 年（平成 6 年） 3 月

\section{高木 方隆, 村井 俊治}

数值地形モデル（DTM）及び人工衛星デー夕（LANDSATTM）を用いて四国の中央部 $13 \times 14 \mathrm{~km}$ を対象に 地すべり解析を試みた。DTM からシェーディング画像・切峰面図・水系図を作成し, 人工衛星データから植生図・ 土地被覆分類図を作成し, 地すべり地の分布状態を考察した。その結果地すべり地は地表水や地中水の集中する 地域に分布しており，地形浸食と密接な関係にあることが判った。

さらに，これらのデータと現地調査および室内実験結果を用いて対象地域内全域の地すべり危険度マップを斜 面安定解析により作成した。その結果，90\%の地すべり防止区域は危険とみられる地域に位置し，良好な結果を 得ることが出来た。

\section{ニューラルネットワークの地すぺり対策杭の設計手法選定への応用}

「地すべり」Vol. 30, No. 4 (通巻第 116 号) pp. 36 40, 1994 年（平成 6 年） 3 月 吉松 弘行, 藤田 無雄

地すべり対策杭は，従来は地すべり地のすべり面形態などの特性要因によりその設計手法が選択されていたが, これまでの既設杭工データをニューラルネットワークを用いて学習させることによって，杭工のたわみ量が予測 でき，ニューラルネットワークが地すべり対策杭設計手法の支援システムになることを示した。

\section{日南海岸（国道 220 号線）の斜面崩壊}

「地すべり」Vol. 30, No. 4（通巻第 116 号）pp. 41～45, 1994 年（平成 6 年） 3 月

高谷 精二

国道 220 号線の宮崎市堀切峠と日南市風田 $29.9 \mathrm{~km}$ 間は, 日向灘に面する急な斜面を切りとった道路のため, しばしば崩壊する。ここで発生する崩壊は次の四つに分類することができた。(1)層厚 5 〜 $15 \mathrm{~m}$ の砂岩のブロック 状崩壊, (2)モルタル剥離崩壊, (3)泥岩上にある砂岩の岩盤すべり, (4)表層土の崩壊。

\section{感圧式すべり面検知器}

「地すへり」Vol. 30, No. 4 (通巻第 116 号) pp. 46～51，1994 年（平成 6 年） 3 月

丸山 清輝, 山崎 宣悦

既存の計測器によるすべり面判定法の問題点を解消するために, 感圧式すべり面検知器の開発を行った。そし て，その精度を確認するために室内及び現地において試験を実施した。その結果，室内試験では，設計通りの性 能を得ることができた。また，現地試験では，累積移動量約 $20 \mathrm{~mm}$ ですべり面深度を求めることができた。 